\title{
Development of Online and Offline Teaching Materials Sprechfertigkeit Niveau B1 Based on Case Study
}

\author{
$1^{\text {st }}$ Tanti Kurnia Sari ${ }^{1}, 2^{\text {nd }}$ Surya Masniari Hutagalung ${ }^{2}, 3^{\text {rd }}$ Siti Kudriyah $^{3}, 4^{\text {th }}$ Indah Aini ${ }^{4}$ \\ \{kurniasaritanti@gmail.com ${ }^{1}$, suryamasniari@unimed.ac.id ${ }^{2}$, kudriyahuut@yahoo.com ${ }^{3}$ \} \\ German Departement of Faculty of Language and Art \\ Universitas Negeri Medan, Indonesia ${ }^{1,2,3,4}$
}

\begin{abstract}
To be ready to face the challenges of future work, Students must speak German fluently. Therefore, this research aims to produce Sprechfertigkeit Niveau B1 teaching material based on the Case Study. This research was conducted at the German Language Education Study Program, State University of Medan. The development step used is the Design-Based Research from Reeves, the development step consists of: (1) Problem Identification, (2) Draft Development, (3) Repeated Testing, and (4) Reflection to Generate Solutions. However, in this research, the development is focused on problem identification and draft development only. The data in this study are qualitative data from books and the internet. The teaching materials developed are adapted to the themes for B1 contained in the Studio Express B1 book. The Themes are: 1) Alltag, 2) MännerFrauen-Paare, 3) Klima und Umwelt, dan 4) Generationen.
\end{abstract}

Keywords: development, teaching materials, online and offline, Sprechfertigkeit Niveau $B 1$, Case Study

\section{Introduction}

To reach the goals of higher education and qualified graduates, the lecturer must create learning activities that accommodate the eight Main Performance Indicators. To achieve the leading performance indicators, we need to provide teaching materials in the learning process that suit the demands of globalization. For example, the ability to speak (Sprechfertigkeit) is one of the essential language competencies to be mastered by students. It is also a sign of students' ability to master the language. So that the teaching material for speaking skills becomes an essential material in the learning. Students must master the ability to speak at the B1 level to prepare themselves for the world of work in the future.

Given the importance of mastering speaking skills, it is crucial to develop speaking skill materials using case studies to develop these materials. Case studies are the basis for material development because when students join the Ausbildung program, they will be interviewed in German. At the interview, prospective participants are usually given a case or problem related to the theme in the Ausbildung program. Therefore, prospective participants must master sufficient vocabulary and respond quickly to cases presented to solve the case correctly. Furthermore, case studies are often used in job application interviews to determine the applicant's ability to solve a problem (complex problem solving). In this digitilizing era, students need to have complex problem-solving competencies. Sigfrid Schefer [1] states that 
to have complex problem-solving competence, one must often be trained to solve cases or face problems. Therefore, admitting case studies in the learning process is the right thing for excellent learning [2].

Due to the current situation and conditions, which require students to learn by themselves wherever they are, the Sprechfertigkeit Niveau Bl speaking skills teaching material is made in the form of modules. Modul, which is also known as the individualizedstudy system or self-passed study course, has been tested as the most effective form for delivering teaching materials [3], [4], [5]. It is a form of delivering material that contains written spoken language and serves as a substitute for lecturer explanations. The material in the module is delivered in full, down to exercises or enrichment. According to Clement [6], teaching materials in modules are more effective if made online. Furthermore, Clement explained that it would be easier to receive and understand the information in the growing age of the digital era if it is conveyed through a network, especially for students who want to learn more practically and effectively.

Based on the explanation above, it is essential to develop teaching materials in the form of online modules for mastering the speaking ability of Sprechfertigkeit Niveau B1. Furthermore, the module will be printed so it can be used in certain areas that are difficult to reach on the internet in terms of a slow network. Thus, the teaching materials developed are in the form of online and offline modules.

\section{Theory}

\subsection{Offline Online Module Development}

The module developed refers to the principle of module development and the characteristics set by the 2008 Directorate General of PMPTK. It must have the following characteristics: 1) Self Instruction, which is a characteristic that must be prioritized in the module, where learners who use the module will be able to learn independently and not rely on a single person (teachers or other parties), 2) Self Contained means that all teaching materials are listed as a whole, so that learners can learn thoroughly, 3) stand-alone means that the module can and should be able to deliver the material ultimately, without relying on media or other learning resources, 4) adaptive means that the module must be following the development of science and technology, and 5) user-friendly or easy to use, means that the module uses simple, easy-to-understand language, and uses commonly used terms.

\subsection{Sprechfertigkeit Niveau B1}

Based on the Common European Terms of Reference (GER), the competencies required for good language use in learning German are divided into six levels: Level A according to the primary language, which is divided into A1 for beginners and A2 as fundamental knowledge. Level B is the level of independent language use. It is divided into two levels, namely level B1 for advanced language use and B2 for independent language use. Finally, level C is proficient language, divided into $\mathrm{C} 1$ for competent language skills, and $\mathrm{C} 2$, which is a level that is close to native speakers. 
According to the guidelines in the book Profile Deutsch, the speaking competence that must be achieved for level B1 is to understand the subject matter in standard language and everyday themes such as work, school, free time, and some others. In addition, it can also express opinions in conversations with native speakers, telling experiences and events, dreams, hopes, and visions.

\subsection{Case Study}

The case study is a learning method that uses a specific reality as material to increase students' knowledge, abilities, and attitudes. Case studies are a form of problem-based learning where situations are put forward to get a solution [7]. Learning by using case studies in the form of scenarios by containing complex information about actual problems or the construction results of various events is hoped to produce solutions to these problems or events. Applying case studies in learning can develop the learner's ability to think analytically and critically in solving a problem and making decisions. In addition, it can also improve the learner's ability to communicate both in writing and orally.

According to Asropi [7], a good case study is a case study that: 1) presents provocative issues, 2) presents empathy for the main problem, 3) focuses on one problem, 4) clear problem statements, and 5) is structured realistically. The application of the case study method in learning can be in role-playing, interviews, class discussions, and written case development.

\section{Research Methods}

The online module development in this study is a development that adapts the Reeves development model [8] (in Akker, 2006), which consists of four main steps, namely (1) problem identification, (2) draft development, (3) iterative trial process, and (4) reflection. However, in this research, the development carried out focuses on identifying problems and developing a draft because this research is early development. The development steps adapted from Reeves started with the collaboration of the Expertise Lecturer Group (KDBK) Sprechfertigkeit team in the German Language Education Study Program. Exchange of thoughts and experiences is carried out at this stage, then jointly identify problems found during learning. After the problems have been appropriately identified, the draft is discussed as an initial solution for developing case study-based teaching materials. At this stage, there is the possibility of several iterative drafts changing. This change can happen because of the various possible solutions to overcome the problems found.

\section{Result And Discussion}

The initial step in developing Sprechfertigkeit Niveau B1-Based Case Study Online teaching materials is to identify learning problems to prepare teaching materials. Based on the identification of problems, an initial draft of the development of case study-based teaching materials was drawn up. Material development is adjusted to Graduate Learning Outcomes (CPL) and Subject Learning Outcomes (CPMK). Based on these two achievements, materials were determined with the development of case studies. CPMK for speaking subject level B1 (Sprechfertigkeit Niveau B1) is that students can express themselves spontaneously and fluently in daily conversation effectively and flexibly and express their opinions appropriately 
on actual themes and daily problems according to level B1. Furthermore, the teaching materials developed are adapted to the themes for B1 contained in the Studio Express B1 book, which is a mandatory textbook for students at the B1 level. The following is an explanation for each theme.

\subsection{Theme: Alltags and Themes: Männer-Frauen-Paare}

These two themes are found in the book Studio Express B1 which is located close together. The Männer-Frauen-Paare theme was studied after the Alltag theme. The Subject Learning Outcomes (CPMK) for the Alltag theme is that students can explain problems in everyday life according to the Alltag theme, while the Männer-Frauen-Paare sub-CPMK is students can describe problems in cross-cultural couple relationships according to the MännerFrauen-Paare theme. From these two themes, case studies can be derived about problems in cross-cultural couple relationships. Because problems related to cross-cultural couples can occur in everyday life, this one case study is considered to represent both themes. Furthermore, problems in the relationship of cross-cultural couples are raised as case studies because cross-cultural couples are currently prevalent, both couples from different ethnicities and couples from different countries, which of course will also have different cultures.

In order for students to understand the problems in cross-cultural couple relationships, two articles are presented with the title Interkulturelle Beziehungen: So gelingen Partnerschaften and Interkulturelle Partnerschaft: So gelingt die Beziehung. Both texts are taken from the internet with the website https://praxistipps.focus.de/interkulturellebeziehungen-so-gelingen-partnerschaften_127800?layout=amp and https://www.berlin.de/special/liebe-und-partnerschaft/3050152-3622272-interkulturellepartnerschaft-so-gelingt.html.

Next, students are divided into small groups. Each group observes the forms of problems in cross-cultural couple relationships, both pairs of different ethnicities or couples from different countries so that forms of problems in cross-cultural couples can be adequately recorded. Each group then documents and explains the forms of these problems. Thus each group can exchange information so that all students get the same learning experience. The form of assignment from this case study is that students play a role by raising a problem in a cross-cultural pair and the solution to that problem. This assignment was recorded on video.

\subsection{Theme: Klima und Umwelt}

Sub Course Learning Outcomes (CPMK) for the theme Klima und Umwelt is being able to retell environmentally friendly ideas according to the Klima und Umwelt theme. In this theme, students learn about climate change and environmental problems. This theme is also very actual in everyday life, so the case study for this theme is fascinating. The case study raised for this theme is the idea of being environmentally friendly. In the learning process, videos are presented about environmentally friendly ideas. Video is taken from Youtube. The first video is titled Umweltschutz im Alltag: Wie geht das richtig? with link https://youtu.be/B7y7EqSGRRQ and Leben ohne Plastik. With link https://youtu.be/9cWrS6c3X4. Through this video, it is hoped that students will open their horizons about saving the environment to have new ideas that they can put into case studies as a step to solving problems. Furthermore, with the guidance of lecturers, students can find and understand new vocabularies according to the Klima und Umwelt theme. Students are also explained and trained in utterances that are following the theme. 
The learning activities were then continued with class discussions guided by the lecturer. Students are divided into several groups. They have to find information about environmentally friendly ideas as material for class discussion. The class discussion aims to find solutions to environmental problems. As a form of assignment, students work in groups to explain environmentally friendly ideas. The presentation was made in the form of a video.

\subsection{Theme: Generationen (Altenheim)}

Sub Course Learning Outcomes (CPMK) for the theme Generationen is that students can express opinions in discussions about Altemheim under the theme Generationen. In this theme, students learn about the stories of the phases of life, especially in the old age phase. In Germany, it is normal for the elderly to live in nursing homes (Altenheim), but this is not the case in Indonesia. The elderly in Indonesia usually live with one of their children, either in their own home or in their child's house. On the other hand, children have an obligation to look after and care for their parents. Of course, these two things are very contradictory, so that it becomes a case study with the theme "Living with Family or in a Nursing Home". First, students are presented with a video about life in a nursing home in Germany with the title Altenheim: Wenn das Leben plötzlich von anderen geregelt wird, which is available at the link https://youtu.be/LR90MccOvZs. Through this video, students get an overview of life in a nursing home in Germany. Next, students are divided into small groups. Each group discussed the advantages and disadvantages of living with family and also living in a nursing home. After all the information was obtained, the discussion continued with a class discussion. The class discussion aims to make students brave and express their opinions according to the CPMK sub for the theme Generationen. In addition, through discussion, students also exchanged information about the concept of a good stay for parents.

Based on Asropi [7] opinion, which has been described previously about the criteria for a good case study, the case studies that appear in each of the above themes are provocative issues and present a sense of empathy for the problem. Thus, it can generate ideas and students' courage to speak. In addition, the case studies have shown above focus on one problem and are arranged as realistically as possible so that students are not confused in expressing their opinions in solving problems. The case studies mentioned above are also applied in several methods. Learning is not monotonous, such as the role-playing method in case studies on cross-cultural couple problems. In a case study on environmentally friendly ideas and a case study on living with family or in a nursing home, students conduct discussions in small group discussions and in-class discussions. Discussions in small groups are intended to help students who have difficulties expressing their ideas and opinions because their group friends assist them. Thus, it is hoped that they will have the courage to express their opinion in a more extensive class discussion.

\section{Conclusion}

Case studies are essential in developing teaching materials for speaking skills at level B1 (Sprechfertigkeit Niveau B1). This is because case studies always appear in every interview when students register for Ausbildung. With the development of case study-based teaching materials, students are expected to have skills in solving problems related to everyday life to have no difficulty when conducting interviews. The case studies developed are provocative and empathetic issues and are arranged as realistically as possible on the themes of 1) Alltag, 2) Männer-Frauen-Paare, 3) Klima und Umwelt, and 4) Generationen. Through this case 
study, students are expected to have an impressive learning experience and raise their courage in speaking and expressing their ideas in accordance with the course's learning outcomes.

\section{References}

[1] Schefer S, Miladinovic I. Developing Complex Problem-Solving Skills: An Engineering Perspective. iJAC. 2019; 12(3): 82.

[2] Herdia, Carvalho, Viera. Designing for Distance Learning in Developing Countries: A Case Study. JOFDL. 2019; 23(1): 5-16.

[3] Ledge. Understanding Self-Study Research. Sage Publishing; 2006.

[4] Appleget, Shimek, Myers, Hogue. A Collaborative Self-Study with Critical Friends: Culturally Proactive Pedagogies in Literacy Methods Courses. STE. 2020; 16(3): 286-305.

[5] Koster B, Bas VDB. Increasing Professional Self-Understanding: Self-Study Research by Teachers with the Help of Biography, Core Reflection and Dialogue. STE. 2014; 10(1):86-100.

[6] Clement Sarah Grand. Digital Learning Education and Skills in the Digital Age. Rand Corporation; 2017.

[7] Asropi. Metode Studi Kasus-Teaching Case. Available at https://www.slideshare.net/AsropiDr/method-studies-teaching-case. [Accessed 12 July 2021.].

[8] Akker, Nieveen, McKenney NS. Educational Design Research" dalam Educational Design Research. New York: Routledge; 2006 